\title{
The seaweed Gracilaria confervoides, an important object for autecologic and cultivation research in the northern Adriatic Sea
}

\author{
G. Simonetti, G. Giaccone and S. Pignatti \\ Istituto Botanico; Trieste, Italy
}

\begin{abstract}
KURZFASSUNG: Die Alge Gracilaria confervoides, ein wichtiges Objekt für autökologische und Kultur-Versuche in der nördlichen Adria. Gracilaria confervoides GREv. ist die einzige nutzbare Rotalge in Italien. Ausgedehnte Kolonien befinden sich in den Lagunen der nördlichen Adria. In diesen Bereichen (Bucht von Goro bei Ferrara) sind von 1968 bis 1969 Untersuchungen über die ökologischen Faktoren (Temperatur, Salinität, Nährsalze, Sauerstoffgehalt) durchgeführt worden, welche die Standorte dieser Rodophycee bestimmen. Für das Wachstum von G. confervoides sind die Buchten der Lagunen mit nährsalzreichem Süßwasserzufluß besonders günstig. Der Zufluß von Süßwasser wirkt einer Temperaturerhöhung während der Sommerzeit entgegen, wodurch das Gedeihen der euryhalinen $G$. confervoides günstig beeinflu\}t wird. Die Algen siedeln an seichten Stellen ( 1 bis $2 \mathrm{~m}$ Tiefe) mit schlammigem Grund. Durch die standortbedingte Wassertrübung ist die Lichtintensität herabgesetzt. $\mathrm{Da} G$. confervoides industriell von Bedeutung ist, wurden in einem Versuchsbereich in der Lagune die Einflüsse der verschiedenen ökologischen Faktoren untersucht. Gleichzeitig wurden Photosynthesemessungen und Biomassebestimmungen durchgeführt.
\end{abstract}

\section{INTRODUCTION}

As part of a research programme devoted to bionomic investigations on the Italian continental shelf, we have studied the algal populations of the northern Adriatic Sea. The associations of benthic algae along the Italian Adriatic coast are restricted to a narrow rocky belt and to the protection dams; there are only limited areas available which have solid substratum suitable for algal attachement. The muddy, sandy and shallow bottoms, are occupied by Zosteraceae (PIgnat'r \& GiacCONE 1967). In some bays (not exposed to wave motion near fluvial affluences) we found extended, almost mono-specific populations of the seaweed Gracilaria confervoides Grev. This alga thrives on hard bottom and develops thick felts consisting of entangled and dense, short-branched long threads (PIgnatTr 1962). The most pronounced extensions of these mono-specific algal populations are localized at Goro near Ferrara, Po delta (Italy), between Po di Goro and Po di Volano.

In the last few years the industry has become interested in these Gracilaria confervoides banks, and a local fishing cooperative periodically collects the algae. After 
a brief superficial drying up in the sun, they are transported to factories for extraction of agar and agaroids.

As this problem is included in our extended research programme and in order to make exploitation of these populations more efficient; we have begun periodic observations in the Bay of Goro. We attempted to establish the various ecological factors that condition setting and development of the alga, as well as the seasonal differences in its growth rates. The algal populations were studied under natural conditions and in an experimental station with closed basins, in the lagoon of Grado. It was possible, to a certain extent, to regulate the ecological conditions in the experimental station.

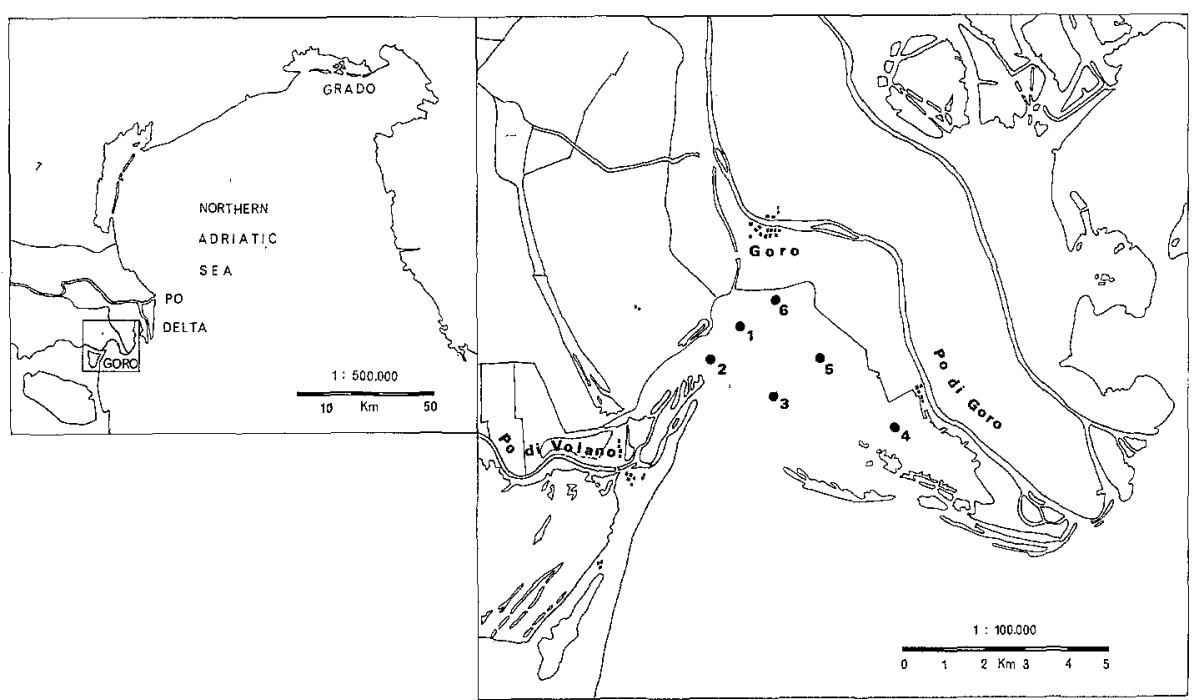

Fig. 1: L ef $\mathrm{t}$ : Northern Adriatic Sea with lagoon belt on the Italian coast. Rig b $\mathrm{t}$ : enlarged area of the "Sacca di Goro" with observations stations, 1-6

\section{INFLUENCE OF VARIOUS ECOLOGICAL FACTORS UNDER NATURAL CONDITIONS IN THE BAY OF GORO}

The "Sacca di Goro" lies near Ferrara in the northern Adriatic Sea. It is a little symmetrical bay limited by the Po di Goro in the East, by the Po di Volano in the West, and partially closed in the South by a semi-submerged bank (Scanno di Piallazza) which protects the bay from becoming covered by sand.

At first, we erected 15 stations in the Sacca at the intersections of an observation net located 800 to $1000 \mathrm{~m}$ apart from each other. In this way the whole area occupied by the Gracilaria confervoides populations was covered. Later, for obtaining average values of the major ecological factors, we selected 6 of these stations situated in strategic spots. 
The circulation of waters from the Po river and irrigation channels represents an ecological factor which more or less affects all other environmental components. The Sacca is influenced almost continuously by fresh and brackish water. During spring, the affluence originates especially from the West branch of the Po river (Po di Volano), which collects the water of the drainage and irrigation channels. In winter, it is the East branch of the Po (Po di Goro) which pours part of its waters from the East

Table 1

Surface (s.) and depth (d.) temperaturs $\left({ }^{\circ} \mathrm{C}\right.$ ) in the Bay of Goro, in different months of the year. Single values in July because of extensive wave motion. Water layers near the bottom are warmer in November

\begin{tabular}{|c|c|c|c|c|c|}
\hline & ations & May & July & September & November \\
\hline \multirow{2}{*}{1} & s. & 20.0 & 23.6 & 23.1 & 11.8 \\
\hline & d. & 18.8 & & 23.8 & 12.2 \\
\hline \multirow{2}{*}{2} & s. & 19.8 & 23.9 & 22.6 & 11.0 \\
\hline & d. & 19.3 & & 23.2 & 11.1 \\
\hline \multirow{2}{*}{3} & s. & 19.8 & 23.3 & 23.2 & 7.7 \\
\hline & d. & 19.4 & & 23.15 & 9.6 \\
\hline \multirow{2}{*}{4} & s. & 20.4 & 22.4 & 23.9 & 7.5 \\
\hline & d. & 19.2 & & 24.0 & 7.6 \\
\hline \multirow{2}{*}{5} & s. & 19.2 & 22.0 & 24.4 & 8.0 \\
\hline & d. & 19.8 & & 23.6 & 9.8 \\
\hline \multirow{2}{*}{6.} & s. & 20.3 & 21.8 & 23.5 & 7.9 \\
\hline & d. & 20.0 & & 23.7 & 10.5 \\
\hline
\end{tabular}

Table 2

Surface (s.) and depth (d.) salinities (\%) in the Bay of Goro, in different months of the year. Conditions in the water column are almost equal in July and September, while remarkable differences occur in May and November (higher values near the bottom)

\begin{tabular}{|c|c|c|c|c|c|}
\hline & tions & May & July & September & November \\
\hline 1 & s. d. & $\begin{array}{r}13.33 \\
18.33\end{array}$ & 20.96 & 7.22 & $\begin{array}{l}24.89 \\
\\
\end{array} 27.76$ \\
\hline 2 & s. $\mathrm{d}$. & $\begin{array}{r}11.73 \\
22.34\end{array}$ & 21.04 & 5.07 & $\begin{array}{l}14.51 \\
\end{array} 26.19$ \\
\hline 3 & s. d. & $\begin{array}{r}17.47_{19.95}\end{array}$ & 19.82 & $\begin{array}{r}22.09 \\
23.70\end{array}$ & ${ }^{10.79} 21.04$ \\
\hline 4 & s. d. & ${ }_{18.30}^{17.12}$ & 12.05 & 9.01 & $\begin{array}{l}\text { fresh } \\
\text { water }\end{array}$ \\
\hline 5 & s. $\mathrm{d}$. & ${ }_{16.35}^{12.00}$ & 18.20 & 17.56 & $\begin{array}{l}3.65 \\
\\
26.19\end{array}$ \\
\hline 6 & s. $\mathrm{d}$. & $\begin{array}{r}11.55 \\
17.95\end{array}$ & 22.36 & 16.91 & ${ }^{10.88} 22.62$ \\
\hline
\end{tabular}


into the Sacca. During the other seasons the two currents are equal in strength to each other. Near the bottom, the water has generally a higher salinity which approaches that of the open sea (maximum: $27 \%$ S).

If sufficiently powerful, wave motion mixes the waters uniformly from surface to bottom. The resulting seasonal fluctuations of salinity and temperature are illustrated in Tables 1 and 2 (MosetTr 1967). Gracilaria confervoides exhibits a remarkable vitality and euryhalinity. Even the extreme salinity range recorded at the different stations does not seem to exert any negative influences on the alga. On the other

Table 3

Surface (s.) and depth (d.) values of dissolved oxygen (mg/l), in the Bay of Goro in different months of the year

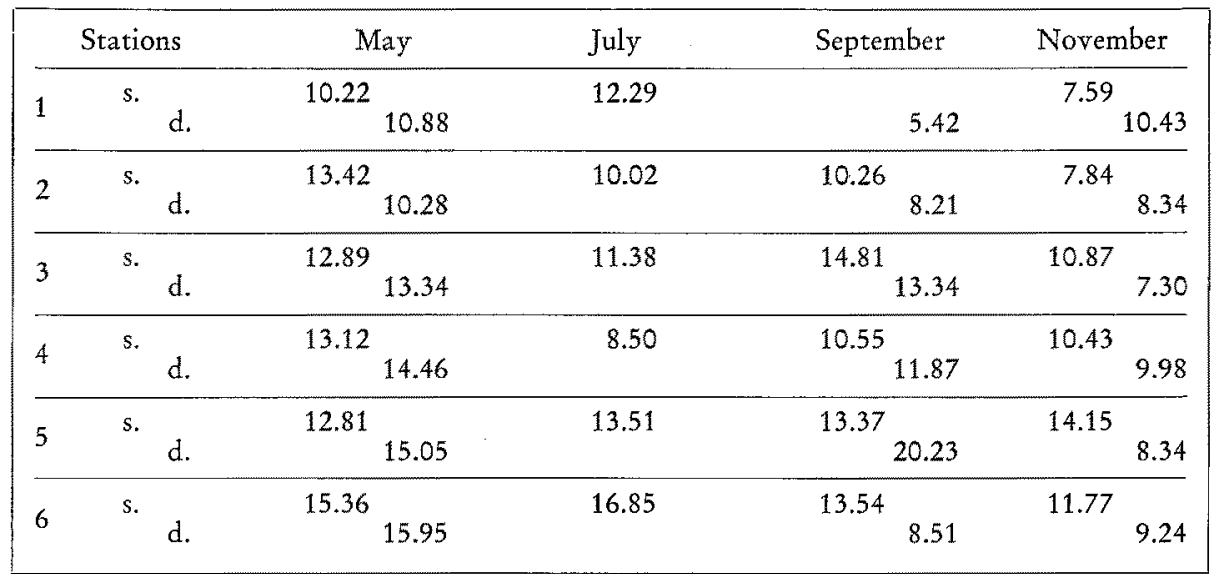

hand, Gracilaria confervoides occurs outside the Sacca di Goro at salinities near $32 \%$ (Lagoon of Grado). The seasonal temperature fluctuations recorded are considerable; they range from $5^{0}-7^{0} \mathrm{C}$ to $24^{0}-28^{\circ} \mathrm{C}$. These values are not excessive when compared with those of the Lagoon of Grado, where large fresh water inflow is missing. In fact, the inflowing fresh water reduces the summer overheating which is a critical factor in the development of Gracilaria confervoides. The data of dissolved oxygen measured reveal rather normal saturation values which are probably due to the continuous, if not intensive, circulation of the waters inside the bay, except some places in "dead corners" of the Sacca (Tab. 3). The considerable inflow of river water produces, in concert with the muddy bottom, permanently high degrees of turbidity; at $1 \mathrm{~m}$ depth (practically at the bottom) light intensity is reduced to $2-3 \%$, and the Secchi disc disappears at $30-40 \mathrm{~cm}$ depth. The water is brownish and the bottom never visible. At other stations in clear water and in the open sea, Gracilaria confervoides thrives at 4-6 $\mathrm{m}$ depth where light intensity is greatly reduced (GIAccoNe 1965).

Nutritive salt (nitrate, phosphate) values are presented in Table 4 (STrickiand \& Parsons 1965). They are considerably higher than in other lagoon localities. Nitrate values are 5 times higher, phosphate values 15 times higher than in Grado. 
These high values are attributable to the significant inflow of waters from irrigation channels crossing agricultural areas treated with fertilizers (FAGANELI 1962). This fertilization effect causes exuberant growth of Gracilaria confervoides in the area studied. The absence of benthonic plant competitors (such as wrackgrasses and seaweeds) due to muddy bottom and intense sedimentation, render the Gracilaria confervoides populations almost mono-specific.

\section{Table 4}

Surface and depth values of micronutrients $(\mu \mathrm{g} / 1)$ measured at 6 experimental stations of Goro and in the Lagoon of Grado, where Gracilaria confervoides populations correspond with the higher values recorded

\begin{tabular}{|c|c|c|c|c|c|c|c|}
\hline $\begin{array}{l}\text { Goro } \\
\text { Stations }\end{array}$ & & 1 & 2 & 3 & 4 & 5 & 6 \\
\hline $\mathrm{N}^{-\mathrm{NO}_{3}}$ & $\begin{array}{l}\text { surface } \\
\text { depth }\end{array}$ & $\begin{array}{r}111.36 \\
55.79\end{array}$ & $\begin{array}{r}138.27 \\
50.87\end{array}$ & $\begin{array}{l}146.0 \\
89.45\end{array}$ & $\begin{array}{l}244.79 \\
154.4\end{array}$ & $\begin{array}{l}136.5 \\
117.82\end{array}$ & $\begin{array}{r}101.95 \\
75.35\end{array}$ \\
\hline $\mathrm{P}_{-} \mathrm{PO}_{4}$ & $\begin{array}{l}\text { surface } \\
\text { depth }\end{array}$ & $\begin{array}{l}4.99 \\
1.56\end{array}$ & $\begin{array}{l}5.21 \\
1.48\end{array}$ & $\begin{array}{l}5.07 \\
1.64\end{array}$ & $\begin{array}{l}7.33 \\
5.47\end{array}$ & $\begin{array}{l}5.11 \\
2.46\end{array}$ & $\begin{array}{l}2.89 \\
2.03\end{array}$ \\
\hline $\begin{array}{l}\text { Lagoon o } \\
\text { Stations }\end{array}$ & f Grado & Fishing resort & Lagoon & \multicolumn{4}{|c|}{ Gracilaria confervoides populations } \\
\hline $\mathrm{N}-\mathrm{NO}_{3}$ & $\begin{array}{l}\text { from } \\
\text { to }\end{array}$ & $\begin{array}{l}3.2 \\
8.4\end{array}$ & $\begin{array}{l}10.34 \\
18.2\end{array}$ & & & & \\
\hline $\mathrm{P}_{-} \mathrm{PO}_{4}$ & $\begin{array}{l}\text { from } \\
\text { to }\end{array}$ & $\begin{array}{l}0.61 \\
0.68\end{array}$ & $\begin{array}{l}0.37 \\
0.40\end{array}$ & & & & \\
\hline
\end{tabular}

The abundant suspended material in the water supports luxurious development of a filter feeding fauna. This fauna provides a suitable substratum on which the algae can settle at the beginning of their life cycle (CHEmrn 1937). However, the filter feeding fauna also affects the alga population in a negative way by using it, in turn, as substratum and thus reduces the commercial value of the dried algal material. Sometimes the epizoic fauna amounts to $30-40 \%$ total weight of the algal material harvested. Gracilaria confervoides exibits seasonal growth and development thythms (Minio 1949). Specimens bearing cystocarps appear during May-June. They are smaller and less branched than vegetative individuals and, unlike, are fixed to shells. Spores are also produced in May-June; the presence of fruiting and sterile specimens is contemporary (FUNK 1957).

\section{INFLUENCE OF TEMPERATURE ON PHOTOSYNTHESIS AT THE EXPERIMENTAL STATION IN THE LAGOON OF GRADO}

Ecological factors have been recorded monthly at the experimental station in the lagoon of Grado. Tufts of Gracilaria confervoides were transferred from a natural station into experimental basins - part of an outdoor area in a fishing resort connected with the lagoon. In these plants and, synchronously, in those of the natural 
station, we studied the influence of temperature and determined the photosynthetic rates during different months of the year.

The low temperature limit for the appearance of Gracilaria confervoides is $15^{\circ} \mathrm{C}$. This temperature level is usually attained or surpassed in the first half of May. When

\section{Table 5}

Temperature and dissolved oxygen values and photosynthesis rates during the vegetative period of Gracilaria confervoides in the lagoon of Grado

\begin{tabular}{|c|c|c|c|c|c|c|c|c|c|}
\hline Parameters & May & June & July & Aug. & Sept. & Oct. & Nov. & Dec. & Jan. \\
\hline $\begin{array}{l}\text { Temperature }\left({ }^{\circ} \mathrm{C}\right) \\
\text { at } 12 \text { a.m. }\end{array}$ & 22.0 & 23.2 & 30.5 & 22.9 & 23.25 & 16.6 & 11.2 & 9.4 & 5.7 \\
\hline Dissolved $\mathrm{O}_{2}(\mathrm{ml} / \mathrm{l})$ & 6.41 & 6.30 & 5.72 & 5.18 & 5.54 & 5.56 & 7.52 & 12.4 & 13.7 \\
\hline$\frac{\mathrm{O}_{2} \mathrm{ml} / 1}{1 \mathrm{~g} \text { dried alga }}$ & 25.8 & 27.9 & 21.8 & 19.48 & 18.83 & 16.38 & 12.67 & 9.40 & 8.59 \\
\hline$\frac{\text { dried }}{\text { fresh }}$ weight $\times 100$ & 14.45 & 11.79 & 12.7 & 13.14 & 13.8 & 17.54 & 18.2 & 19.87 & 20.1 \\
\hline
\end{tabular}

this minimum temperature is again reached at the end of October the plants enter a very evident stage of reduced metabolic activity and the areas of dead tissue increase. This becomes evident if one compares the values for dry weight and the rates of photosynthesis (Tab. 5, Fig. 2).

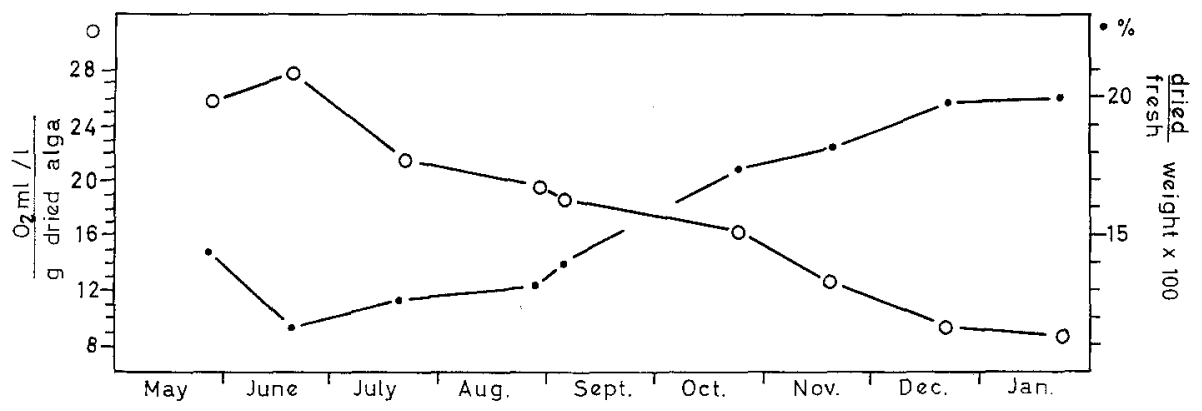

Fig. 2: Gracilaria confervoides. Photosynthesis rates and percentage weight during the vegetative period

At the 2 stations the critical value of $15^{\circ} \mathrm{C}$ occurs approximately at the same time, but the water in the fishing resort is heated more rapidly in spring ( $25^{\circ}$ against $19^{\circ} \mathrm{C}$ at the natural station). This difference is even more pronounced in summer; the diurnal thermal fluctuation amounts to $10 \mathrm{C}^{0}$ in the resort (minimum: $20^{\circ} \mathrm{C}$; maximum: $31^{\circ} \mathrm{C}$, July 1968) while in the lagoon it amounts to $4^{0} \mathrm{C}$ only (minimum: $22^{\circ} \mathrm{C}$; maximum: $26^{\circ} \mathrm{C}$ ), as shown in Figure 3. Because of the relative small water volume, in the fishing resort, the temperature minimum is frequently 2 or $3 \mathrm{C}^{0}$ lower than in the open lagoon owing to extensive night cooling. This has no negative consequence as the threshold temperature of $15^{\circ} \mathrm{C}$ is always largely exceeded. 
The maximum temperature values are, therefore, the most important ones; in the fishing resort they influence directly the metabolic activity of Gracilaria confervoides because the solubility of gases becomes significantly reduced especially since, in this location, lack of sufficient water movement reduces gas transport (LAUSI et al. 1967). The whole water mass, with an average depth of about $1 \mathrm{~m}$, has not the same temperature. In contrast in the lagoon channels the moving waters are homeo-thermic. Maximum temperatures are confined to the uppermost $20 \mathrm{~cm}$ of the water column; within $1 \mathrm{~m}$ there is often a gradient of $5 \mathrm{C}^{0}\left(30^{\circ}\right.$ at surface; $25^{\circ} \mathrm{C}$ at $1 \mathrm{~m}$; July 1968); at $1 \mathrm{~m}$ depth the temperature corresponds to that of the outside lagoon waters.

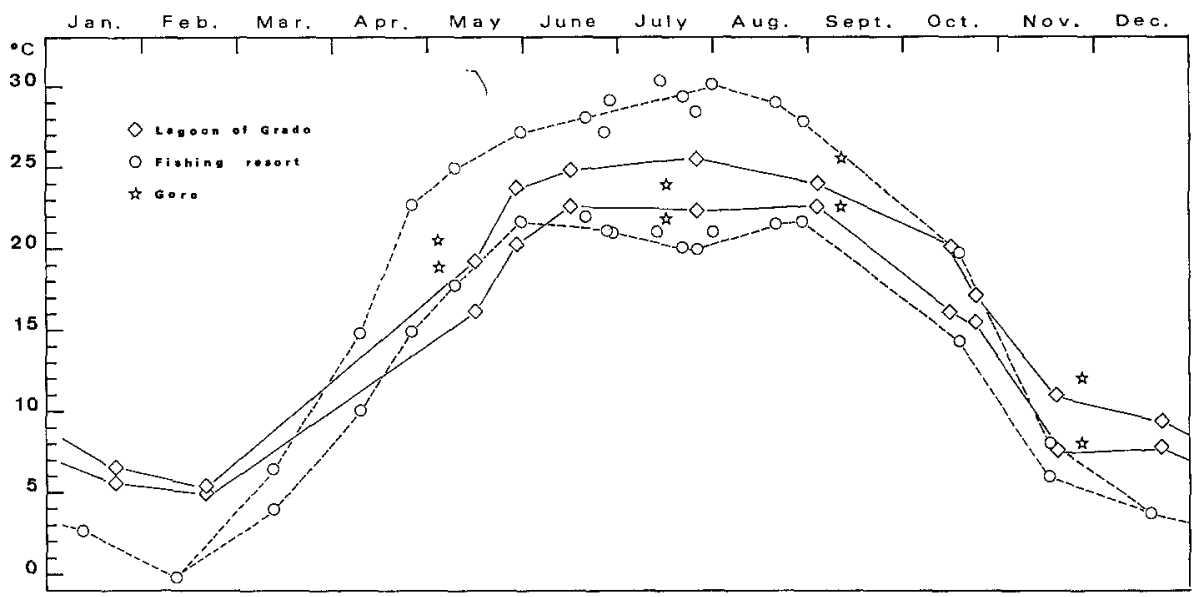

Fig. 3: Diurnal thermal fluctuations (daily maximum and minimum values) in the Lagoon of Grado and in the fishing resort

The overheated superficial water layer can be removed and thus lagoon conditions established in the fishing resort. During a test in a basin, a layer of $5 \mathrm{~cm}$ surface water was removed by making use of the difference in the outside ebb tide level; the surface temperature dropped from $27.5^{\circ} \mathrm{C}$ to $25^{\circ} \mathrm{C}$ in the warmest place (within $10 \mathrm{~min}$; total water volume: $1600 \mathrm{~m}^{3}$ ). In order to create the best conditions for cultivation of Gracilaria confervoides sufficient water exchange, simulating tidal currents at the natural stations, appear to be desirable. In this way the temperature variations can be kept at a level similar to that in the outside lagoon $\left(3 \mathrm{C}^{0}\right.$ variation against 8 to $\left.10 \mathrm{C}^{0}\right)$.

In the natural habitat (Sacca di Goro) the diurnal thermic variation amounts to 3 to $4 \mathrm{C}^{0}$ during the whole summer, with maximum values towards the end of the summer (September 1968: 270 C). In this habitat, the extended circulation of water from the River Po limits excessive heating in spite of the shallow bottom (1 $\mathrm{m}$ average depth). Our observations made in the natural habitat and in the experimental station, allow us to come to the conclusion that Gracilaria confervoides is a euryhaline and especially nitrophile alga. Luxurious populations grow on muddy bottoms of about $1 \mathrm{~m}$ depth; sterile vegetative forms develop best during the summer. 


\section{SUMMARY}

1. The seaweed Gracilaria confervoides GrEv. is the only source of agar extraction in Italy. Large populations are present in the coastal lagoons of the Northern Adriatic Sea. In these habitats (e.g. Bay of Goro near Ferrara) periodical recordings were made during 1968 and 1969 of temperature, salinity, micronutrients, light intensity and $\mathrm{O}_{2}$ concentration.

2. The lagoon bays offer the best condition for the development of Gracilaria confervoides populations, especially near places of fresh water inflow containing large amounts of nutrients. Fresh water inflow also limits critical temperature rise during summer.

3. The natural habitat is shallow (average depth: $1 \mathrm{~m}$ ); since the bottom is muddy, the water is very turbid and the light intensity significantly reduced.

4. Gracilaria confervoides lies unanchored on the mud in the vegetative sterile form in long densely branched threads, while the spores settle on shells.

5. In view of the industrial importance of this alga, we have established an experimental cultivation field in a lagoon fishing resort in order to assess the influence of various ecological factors. This study was made from 1968 through 1969 together with productivity tests (photosynthesis rates and biomass measurements).

Acknowledgement: We are grateful to Professor D. LAusr for micronutrients measurements.

\section{LITERATURE CITED}

Chemin, E., 1937. Le développement des spores chez les Rhodophycées. Revue gén. Bot. 49, 205. Funk, C., 1957. Fruktifikationszeiten der Meeresalgen bei Neapel. Pubbl. Staz. zool. Napoli 29, 126-138.

Giaccone, G., 1965. Le fitocenosi marine nel settore rosso di Capo Zafferano (Palermo). Lav. R. Ist. bot. Palermo 22, 1-69.

Lausi, D., Cristofolini, G., Tarabocchia, M. \& Cristini, P. De, 1967. Attività fotosintetica di alghe marine nella Grotta delle Viole (Isole S. Domino-Tremiti). Nuovo G. bot. ital. 101, 167-178.

Mrnio, M., 1949. Opposte fasi di esuberanza e ricchezza cistocarpica nella propagazione di Gracilaria confervoides GREv. Nuovo G. bot. ital. 56, 298-301.

MosetTi, F., 1967. Temperature e salinità nel Golfo di Trieste. Adriatico 5/6, 1-6.

Paganelil, A., 1962. Primi risultati relativi alla concentrazione dei sali nutritivi nelle acque del Mare Mediterraneo Centrale e mari adiacenti. Archo Oceanogr. Limnol. 12, 192-208.

Pignattr, S., 1962. Associazioni di alghe marine sulla costa Veneziana. Memorie R. Ist. veneto Sci. 32 (3), 1-134.

- \& GIaccone, G., 1967. Studie sulla produttività primaria del fitobentos nel Golfo di Trieste. Flora sommersa del Golfo di Trieste. Nova Thalassia 3 (1).

Strickland, J. D. H. \& Parsons, D. R., 1965. A manual of sea water analysis. 2nd ed. Bull. Fish. Res. Bd Can. 125, 1-203.

First author's address: Dr. G. Simonetri

Istituto Botanico

Università degli studi di Trieste

Via Valerio 30

Trieste, Italia 